\title{
Studying the Genetic Variation Among Low and High Milk Producer Egyptian Buffalo (Bubalus bubalis) using Microsatellite and Scot Markers Nerdeen M. AbdelMoneam ${ }^{1}$; H. S. Zein ${ }^{2}$; Laila R. Hassan ${ }^{3}$; Dina El-Khishin ${ }^{1}$ and Naglaa A. AbdAllah ${ }^{2}$ \\ ${ }^{1}$ Agricultural Genetic Engineering Research Institute, Agricultural Research Center \\ ${ }^{2}$ Genetics Department, Faculty of Agriculture, Cairo University \\ ${ }^{3}$ Animal Production Research Institute, Agricultural Research Center
}

\section{ABSTRACT}

The future bio-economy of dairy industry relies on the identification of an affordable approach for increasing milk production and its constituents. Egyptian buffalo (Bubalus bubalis) contributes by about $50 \%$ of total milk production in Egypt, therefore it is considered as an essential dairy animal. This study aimed to differentiate between high and low milk producer buffaloes (Bubalus bubalis) using microsatellite and SCoT markers. The results of the six microsatellite primers showed bands of 350, 377, 496, 247, 262 and $280 \mathrm{bp}$, where three of which were digested by restriction enzyme. SCoT results of bulked samples showed unique bands that were sequenced and aligned to Bubalus bubalis (taxid: 89462) sequences. Alignment results showed similarity to the following encoding genes, Class V myosin, Ubiquitin-conjugating enzyme E2 D4 and acyl-phosphatase 2 (ACYP2), which play a crucial role in organelle trafficking and many pathways, that may affect milk production traits. These results showed that SCoT marker was better than microsatellite in clarifying the difference between high and low milk producing traits in Egyptian buffalo (Bubalus bubalis).

Keywords: Bubalus bubalis, SCoT, microsatellite markers

\section{INTRODUCTION}

The world population is increasing at a rapid rate and is expected to reach $8-9$ billion by the end of 2030 . Consequently advancements in scientific and technological fields linked to animal production and related biotechnologies are urgently needed (Deb et al., 2016). In Egypt buffaloes fed on poor quality nutritional resources, like crop-residues and industrial by-products containing high fibrous materials, due to their ability to utilize poor value feed resources. This is the main reason why water buffalo (Bubalus bubalis) is considered as an efficient converter of poor quality resources into high quality milk and meat, in addition to power, fuel, and by-products such as hides, hoof, and bones, as well as manure to be used as fertilizer (Qureshi et al., 2002; Sarwar et al., 2009).

Buffaloes are also more resistant to many diseases than domestic livestock. This feature helps buffalo to survive in hot humid regions (Marai et al, 2010). However, improper feeding regimen and low food availability and quality certainly have a negative impact on reproductive and productive performances, by increasing mortality rates, longer calving interval, and reduction of growth rates (Tiwari et al., 2007; Pasha and Khan, 2010). Buffalo population is distributed worldwide, even though the majority (around 97\%) present in Asia, and 3717 million are in Africa, mostly in Egypt (2.24 \%); 3.3 million. Buffaloes are the second largest source of milk worldwide, in Egypt it contributes by about $50 \%$ of total milk production - 1041533 heads- with Lactation duration of 210-280 days, and Milk yield of 2034030 tones (FAOSTAT 2017). Buffalo milk is more preferred by the consumer for its white color and rich nutrition as it contains higher content of fat (6.5-7.0 \%), lactose, casein, whey proteins, and minerals than cow milk, which is responsible for its high energy and nutritive value. Therefore, it is more desired in several dairy industries as cheese, yogurt and ice cream (Hamad et al., 2014; Khedkar et al., 2016). Egypt suffers from a massive gap in milk and meat production, detected through annual imports. Recent studies give more attention for genetic improvement of domestic buffalo breeds to increase their role in the agricultural production system (Borghese, 2005; FAOSTAT 2017).

Molecular markers are essential in identifying any phenotypic difference that is genetically controlled. In addition, molecular markers are also used to discriminate groups of individuals (Reinosa and Abad, 2012). One of the main critical molecular markers are microsatellite markers, which are repetitive regions of DNA where short nucleotide sequences (ranging in length from 1-6 or more bp) are repeated 5-50 times, and the number of repeats differs between individuals of the same species. They have high mutation rates than other areas of DNA, which results in high genetic diversity (Brinkmann et al. 1998; Richard et al., 2008; Gulcher 2012). PCR-RFLP is the amplification of genes with specific primers, and then the amplified PCR products are subjected to digestion using restriction enzymes (Reinosa et al., 2012). K-casein gene: $\mathrm{K}$-casein is a milk protein that determines the size and function of milk micelles, also caseins are raw materials for cheese making industry (Otaviano et al. 2005; Shende et al., 2009). Leptin gene: Leptin is a hormone occupied in the regulation of nourishment intake, fat metabolism, and reproduction. A primer amplifying the exon 3 of the leptin gene is used to detect any SNPs that may be related to milk production (Vallinoto et al., 2004). $\beta$ - lactoglobulin gene: $\beta$ lactoglobulin is a milk protein that is related to milk production. It has a main influence on the composition of milk and on the processing property of milk (Meignanalakshmi et al., 2009). Start codon targeted polymorphism (SCoT) gene expression analysis is vital in studying genetic difference; which is mainly based on short conserved region flanking the ATG start codon in plant genes. It was known that SCOT method uses single primers of 18-mer in single primer polymerase chain (Wu et al., 2013). These primers are start codon targeted, which would help in studying the expressed genes regardless RNA complications. SCoT primers were used after verifying their sequence similarity to the published buffalo sequences found in the NCBI website. This study aimed to relate some sequences of buffalo milk genes with the milk production traits and to discriminate the difference between high and low milk producing animals. 


\section{MATERIALS AND METHODS}

Animal blood samples and DNA extraction:

Twenty Egyptian Buffaloes blood samples were kindly provided by Animal Production Research Institute (APRI). Those animals were divided into two groups according to their breeding value. The first group (12 animals) was high producers and the second group (8 animals) was low milk producers. The blood samples were collected using falcon tubes containing $200 \mu$ EDTA from the jugular vein and stored at $-20^{\circ} \mathrm{C}$ until processed. DNA was extracted from frozen blood according to thermo scintific Kit protocol. DNA samples were quantified using NANO drop. DNA samples were then checked on $1 \%$ agarose gel.

Microsatellite markers:

Six microsatellite primers were selected from previous studies to detect different milk genes (Table 1).

Table 1.Primers names, sequences, milk genes, expected fragment size, the restriction enzyme and reference.

\begin{tabular}{|c|c|c|c|c|c|}
\hline $\begin{array}{l}\text { Primer } \\
\text { name }\end{array}$ & $\begin{array}{c}\text { Primer } \\
\text { sequence 5' } \rightarrow \text {, }\end{array}$ & Gene & $\begin{array}{l}\text { Expected } \\
\text { fragment } \\
\text { size }\end{array}$ & $\begin{array}{c}\text { Restriction } \\
\text { enzyme } \\
\text { used }\end{array}$ & Reference \\
\hline $\begin{array}{l}\mathrm{JK} 5-\mathrm{F} \\
\mathrm{JK} 3-\mathrm{R}\end{array}$ & $\begin{array}{l}\text { ATCATTTATGGCCATTCCACCAAAG } \\
\text { GCCCATTTCGCCTTCTCTGTAACAGA }\end{array}$ & $\begin{array}{c}\mathrm{k}- \\
\text { casein }\end{array}$ & 350-bp & HinfI & Stipp et al., 2013 \\
\hline $\begin{array}{l}\mathrm{K} 1-\mathrm{F} \\
\mathrm{K} 2-\mathrm{R}\end{array}$ & $\begin{array}{c}\text { CCCACCGAGTCCTGCCAC } \\
\text { GTTGAAGGACTTAAAGGAGA }\end{array}$ & $\begin{array}{c}\mathrm{k}- \\
\text { casein }\end{array}$ & $377 \mathrm{bp}$ & None & Damiani et al., 2000 \\
\hline $\begin{array}{l}\text { Exon3-F } \\
\text { Exon3-R }\end{array}$ & $\begin{array}{l}\text { CCCTCTCTCCCACTGAGCTC } \\
\text { TAAAGGATGCCCACATAGGC }\end{array}$ & Leptin & 496 bp & None & Orrù et al., 2007 \\
\hline $\begin{array}{l}\text { Lac-10-F } \\
\text { Lac-10-R }\end{array}$ & $\begin{array}{l}\text { TGTGCTGGACACCGACTACAAAAA } \\
\text { GCTCCCGGTATATGACCACCCTCT }\end{array}$ & $\begin{array}{c}\beta- \\
\text { lactoglobulin }\end{array}$ & $247 \mathrm{bp}$ & Hae III & Karimi et al, 2009 \\
\hline $\begin{array}{l}\mathrm{I}-10-\mathrm{F} \\
\mathrm{II}-10-\mathrm{R}\end{array}$ & $\begin{array}{l}\text { GTCCTTGTGCTGGACACCGACTACA } \\
\text { CAGGACACCGGCTCCTGGTATATGA }\end{array}$ & $\begin{array}{c}\beta- \\
\text { lactoglobulin }\end{array}$ & 262 bp & Hae III & $\begin{array}{l}\text { Meignanalakshmi et al., } 2009 \\
\text { Stipp et al., } 2013\end{array}$ \\
\hline $\begin{array}{l}\text { ex1-10-F } \\
\text { ex2-10-R }\end{array}$ & $\begin{array}{l}\text { TGTGCTGGACACCGACTACAAAAAG } \\
\text { GCTCCCGGTATATGACCACCCTCT }\end{array}$ & $\begin{array}{c}\beta- \\
\text { lactoglobulin }\end{array}$ & $280 \mathrm{bp}$ & Hae III & Ilie et al., 2010 \\
\hline
\end{tabular}

Polymerase chain reaction-restriction fragment length polymorphism PCR-RFLP

PCR amplification was performed in a final volume of $25 \mu$ containing $50 \mathrm{ng}$ DNA, $(10 \mathrm{pM} / \mu \mathrm{l}) 1 \mu \mathrm{l}$ of each primer and $(5 \mathrm{u} / \mu \mathrm{l}) 0.15 \mu \mathrm{l}$ GoTaq ( Promega) $5 \mathrm{x}$ green buffer (Promega) $5 \mu \mathrm{l}$ and $(2 \mathrm{mM}) 2.5 \mu \mathrm{ldNTPs}$ and $1 \mathrm{ml}$ $\mathrm{MgCl} 2$. The amplification reaction was performed using PCR profile with an initial cycle at $95^{\circ} \mathrm{C}$ for $5 \mathrm{~min}$, followed by 35 cycles of $95^{\circ} \mathrm{C}$ for $30 \mathrm{sec}$., $60^{\circ} \mathrm{C}$ for 30 sec. and $72^{\circ} \mathrm{C}$ for $30 \mathrm{sec}$., and a final extension at $72^{\circ} \mathrm{C}$ for 7 min. Thereafter, PCR products were digested with restriction enzymes in a $20 \mu \mathrm{l}$ of restriction mixture (10U R.E / reaction) and the digestion reaction were incubated at $37^{\circ} \mathrm{C}$ for 20 minutes and then terminated by increasing the temperature to $80^{\circ} \mathrm{c}$ for 15 minutes.

SCoT markers:

Fifteen SCoT primers were used in this study. All primers aligned with Bubalus bubalis (taxid: 89462) sequences using the Basic Local Alignment Search Tool (BLAST) in the National Center for Biotechnology Information (NCBI) database. Thus SCoT primers were used to identify expressed genes for the first attempt in Egyptian buffalo Bubalus bubalis (Table 2).

Table 2. SCoT primer sequences used in all the 20 samples.

\begin{tabular}{ll}
\hline Primer number & Primer sequence 5' $\rightarrow \mathbf{3}^{\prime}$ \\
\hline 1 & CAACAATGGCTACCACCA \\
2 & CAACAATGGCTACCACCC \\
11 & AAGCAATGGCTACCACCA \\
13 & ACGACATGGCGACCATCG \\
16 & ACCATGGCTACCACCGAC \\
33 & CCATGGCTACCACCGCAG \\
35 & CATGGCTACCACCGGCCC \\
\hline
\end{tabular}

Bulked samples

SCoT primers used to amplify bulked genomic DNA representing high and low milk production traits, generated by mixing equal concentration from six of the
DNA highest and lowest milk producer according to the breeding value. (Al-Soudy et al., 2018).

Table 3. SCoT primers sequences used in bulked samples.

\begin{tabular}{ll}
\hline Primer Number & Primer sequence $\mathbf{5}^{\rightarrow} \rightarrow \mathbf{3}^{\prime}$ \\
\hline 1 & CAACAATGGCTACCACCA \\
2 & CAACAATGGCTACCACCC \\
3 & CAACAATGGCTACCACCG \\
4 & CAACAATGGCTACCACCT \\
11 & AAGCAATGGCTACCACCA \\
12 & ACGACATGGCGACCAACG \\
13 & ACGACATGGCGACCATCG \\
14 & ACGACATGGCGACCACGC \\
16 & ACCATGGCTACCACCGAC \\
20 & ACCATGGCTACCACCGCG \\
22 & AACCATGGCTACCACCAC \\
28 & CCATGGCTACCACCGCCA \\
33 & CCATGGCTACCACCGCAG \\
35 & CATGGCTACCACCGGCCC \\
36 & GCAACAATGGCTACCACC \\
\hline
\end{tabular}

Bands purification, sequencing and data analysis:

Only three of the polymorphic bands were excised and purified using Invitrogen purification kit, for sequencing. Sequencing was performed using Big Tri Dye sequencing kit (ABI Applied Biosystem). The sequences of the three bands were aligned with Bubalus bubalis (taxid:89462) sequence using The Basic Local Alignment Search Tool (BLAST) in the National Center for Biotechnology Information (NCBI) data base, using the database (nucleotide collection (nr/nt), and then aligned using the database [whole-genome shotgun contigs (wgs)].

\section{RESULTS AND DISCUSSION}

Results

\section{Animal selection}

Milk production quantity wasn't the only factor for animal selection in this study; it was subjected to different criteria as number of milking seasons and the average 
number of milk production in each season. Moreover sire genes contributes in milk production traits of their daughters as well as dames genes. Accordingly animal selection was based on breeding value that gives evidence on milk production traits, as samples from 1 to 12 are of high BV and samples from 13 to 20 are of low B.V (Table 4).

Table 4. Animal number, B.V. (breeding value), sire number, dame number, dame weight at calving, milk production at sampling season and number of milk production season for each buffalo.

\begin{tabular}{|c|c|c|c|c|c|c|}
\hline $\begin{array}{l}\text { Animal } \\
\text { No. }\end{array}$ & B. $V^{\mathrm{a}}$ & Sire & Dame & $\begin{array}{c}\text { Weight of dame at } \\
\text { calving (Kg) }\end{array}$ & $\begin{array}{l}\text { Milk production at sampling } \\
\text { season }(\mathbf{K g})^{\mathbf{b}}\end{array}$ & $\begin{array}{c}\text { Milking Seasons } \\
\text { number }\end{array}$ \\
\hline 1 & $* 106.8$ & 12043 & 14853 & 550 & 2117 & 6 \\
\hline 2 & $* 103$ & 13066 & 14746 & 550 & 1766.5 & 5 \\
\hline 3 & $* 81$ & 13066 & 2845 & 500 & 2105 & 2 \\
\hline 4 & $* 60$ & 12933 & 2774 & 400 & 1865 & 6 \\
\hline 5 & $* 58$ & 1361 & 2966 & 400 & 1691 & 2 \\
\hline 6 & $* 56$ & 13066 & 2863 & 550 & 1544 & 3 \\
\hline 7 & $* 51$ & 12933 & 2914 & 550 & 1847 & 6 \\
\hline 8 & $* 47$ & 18038 & 15253 & 580 & 1941.5 & 6 \\
\hline 9 & $* 40$ & 14727 & 16529 & 570 & 1801 & 12 \\
\hline 10 & $* 27$ & 14727 & 14746 & 550 & 2096 & 10 \\
\hline 11 & $* 18$ & 12148 & 2007 & 450 & 2302 & 10 \\
\hline 12 & $* 8$ & 12043 & 2629 & 580 & 1704 & 10 \\
\hline 13 & 0 & 17224 & 2272 & 550 & 2016.5 & 11 \\
\hline 14 & -73 & 13442 & 2206 & 550 & 1544 & 1 \\
\hline 15 & -49 & 1361 & 1740 & 450 & 1559 & 2 \\
\hline 16 & -44 & 13061 & 2903 & 400 & 1934 & 6 \\
\hline 17 & -40 & 1361 & 2902 & 500 & 2119 & 4 \\
\hline 18 & -22 & 12043 & 16085 & 580 & 1716 & 5 \\
\hline 19 & -22 & 15280 & 2262 & 550 & 1532 & 10 \\
\hline 20 & -2 & 12043 & 2074 & 550 & 1655 & 10 \\
\hline
\end{tabular}

${ }^{a} \mathrm{~B}$.V. breeding value (it is used to clarify high and low milk producing individuals).

${ }^{b}$ Milk production at sampling season (season when blood sample was taken).

* High producers.

- Low producers.

Microsatellite markers and PCR-RFLP:

Most of the used microsatellite primers provide monomorphic results. Only three primers showed polymorphism between individual samples within $\beta$-LG gene. Namely, primer I-10 amplifying the $\beta$-LG gene from exon IV to intron IV that resulted in a $262 \mathrm{bp}$ fragment (Fig. 1A), Primer ex-10 amplifying a $280 \mathrm{bp}$ fragment and Primer Lac-10 amplifying $247 \mathrm{bp}$. These fragments were then subjected to digestion by Hae III enzyme. Digestion resulted in different fragments which differ in number between different individuals (high and low producers), with no significant differences between high and low yielders (Fig. 1 B).

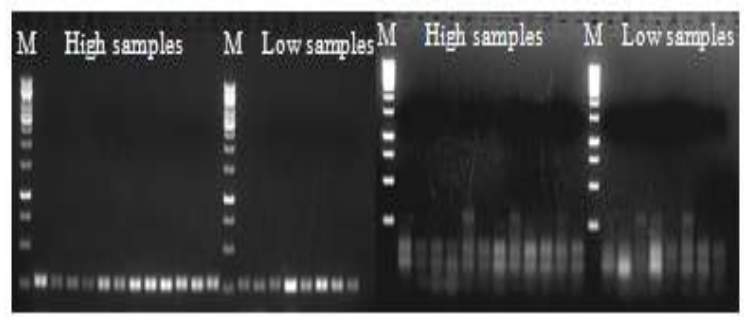

(A)

(B)

Fig .1. ( A) Primer I-10 amplifying $\beta$-LG gene from exon IV to intron IV, (B) Result of digestion of the band by Hae III enzyme. (M) Marker 1kb Ladder, High samples (1-12), Low samples (13-20).

\section{SCoT primers}

Most of the SCoT primers used resulted in monomorphic profiles (Fig. 2).

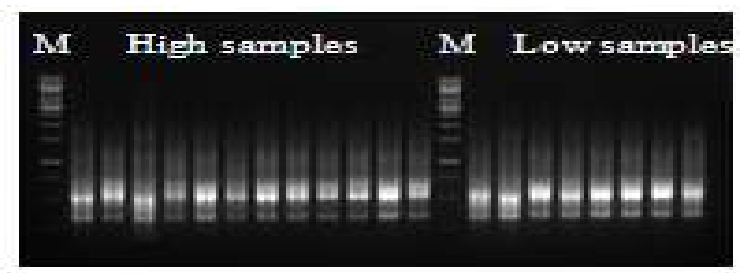

primer 16

Fig . 2. SCoT marker result. (M) Marker 1kb Ladder, High samples (1-12), Low samples (13-20).

\section{Bulked samples}

Fifteen different SCoT primers were used to detect the difference in the bulked samples representing high and low milk production traits (Table 3). Only three of the polymorphic bands were excised and purified.

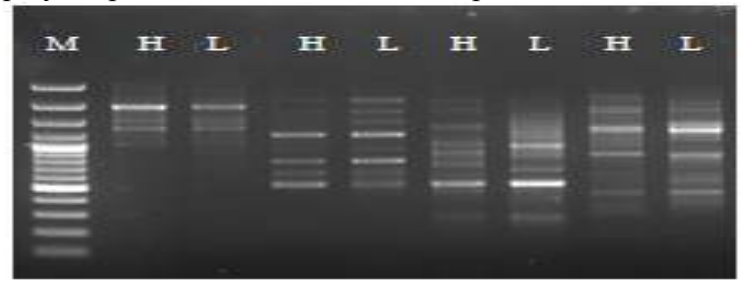

Fig . 3. Results of bulked samples amplification using primers (p3, p4, p12, and p14) respectively from left side, (H) represent high yielders (L) represents low yielders, (M) $1 \mathrm{~kb}$ Marker.

Sequencing and analysis of amplified bands:

The three sequenced bands contained 543, 528, and 534 nucleotides, respectively. First sequence had 543 nucleotides and showed similarity to the gene expressing Class V myosin with accession number: XM_025295606, 
when using (nr/nt) database, This sequence when aligned using the (wgs) database it showed greater similarity to the Bubalus bubalis genome. It resulted in similarity to Mediterranean breed chromosome 6 accession number PZYV01000021, 11, 9 and 2, and some contigs and scaffolds.

Second sequence had 528 nucleotides and showed similarity to the gene expressing Ubiquitin-conjugating enzyme E2 D4 with accession number: XM_006074776, when using (nr/nt) database, This sequence when aligned using the (wgs) database it showed greater similarity to the Bubalus bubalis genome. It resulted in similarity to Mediterranean breed chromosome 6 accession number PZYV01000021, X, 4, 23 and 2, and some contigs and scaffolds.

Third sequence had 534 nucleotides and showed similarity to the gene expressing acyl-phosphatase 2 (ACYP2) with accession number: XM_025261021 using (nr/nt) database. This sequence when aligned using the (wgs) database it showed greater similarity to the Bubalus bubalis genome. It resulted in similarity to Mediterranean breed chromosome 4 accession number PZYV01000019, 3, 19, 13 and 10, and some contigs and scaffolds.

\section{Discussion}

In the present study six microsatellites were used for screening different milk genes. Primer K1 amplifying 377 bp of K- casein gene, and primer exon 3 amplifying $496 \mathrm{bp}$ of exon3 leptine gene, resulted in monomorphic profile detecting no SNPs that may be related to milk production traits. $\beta$ - lactoglobulin gene amplification resulted in a 262, 280, and 247 bp bands using three different primers. In addition, digestion reaction using Hae III enzyme resulted in different bands which differ in number. However, it is impossible to assess the influence of these genes on milk production traits, since all animals in this study showed non-significant difference between high and low milk producing animals.

It may be the first attempt to use SCoT primers to identify expressed genes in Egyptian buffalo Bubalus bubalis. The results were able to amplify buffalo DNA samples, providing a monomorphic profile. Nevertheless, we weren't able to differentiate between high and low milk producers' animal.

SCoT primers that were used on two bulked samples representing the high and low milk yielders; provides unique bands, therefore the results were able to differentiate between high and low yielders. Only three of the purified bands were sequenced.

First sequence had 543 nucleotides and showed similarity to the gene expressing Class V myosin, which are group of molecular motors. Class $\mathrm{V}$ myosins have a preserved structure that can be divided into a head, neck, and tail. One of the class V myosins is Myo5 which is divided to $\mathrm{a}, \mathrm{b}$ and $\mathrm{c}$, Myo5 is expressed intensively in many tissues as brain, epithelial and glandular tissues including pancreas, prostate, mammary, stomach, colon and lung (Olga et al., 2002). Although class V myosins plays critical roles in organelle trafficking and have been the subject of intensive research, relatively little is known about the localization, dynamics, or functions of Myo5c. Mammals express three different class Vmyosins, myosin-
Va (Myo5a), myosin-Vb (Myo5b), and myosin-Vc (Rodriguez and Cheney, 2002).

In a previous study, the first immunolocalization of endogenous Myo5c in a cell line and the first live-cell imaging of GFP-Myo5c was reported by Jacobs et al., (2009). This study revealed that Myo5c localizes the secretory granules; consequently that dominant negative Myo5c dramatically perturbs the distribution of secretory granule markers. Accordingly, this results was able to define the fundamental cell biology of Myo5c and prove that Myo5c functions as a molecular motor in the trafficking of exocrine secretory granules. Additionally, our investigations provide a strong evidence that Myo5c associates with secretory granules and is required for normal secretory granule trafficking.

Previous studies indicated that Myo5c localizes on mature exocrine secretory granules in rabbit lacrimal gland acinar cells (Marchelletta et al., 2008). Interestingly, the expression of Myo5c tail partially inhibits carbachol which consequently stimulates secretion, indicating that Myo5c is required for normal secretion in actual exocrine secretory cells. In accordance to a previous study, it was reported that Myo5c is a class $\mathrm{V}$ myosin that functions in the trafficking of exocrine secretory granules (Chen et al., 2006).

Throughout aligning the resulted sequence against Bubalus bubalis genome using (wgs) database, results showed greater similarity. Hence the provided sequence showed similarity to chromosome 6 , where the relation between some chromosome 6 expressed genes or sequences and milk production was determined, as well as the same for chromosomes 11, 9 and 2 .

Results showed that similar sequences are related to milk production especially the sequence that was isolated from the bulked low breeding value animals, which may indicate that the presence of such a sequence is truly related to low milk producing animals. Nevertheless, more developments are required to verify this study.

The second sequence had 528 nucleotides and showed similarity to the gene expressing Ubiquitinconjugating enzyme E2 D4, which functions as an acceptance of ubiquitin from the E1 complex and catalyzes it to covalently attach to other proteins, one of its other functions is membrane trafficking (David et al, 2010). One of its functions is an impact on membrane trafficking. The manner in which ubiquitin is added determines the outcome for the protein. These modifications can include: monoubiquitination, the addition of a single ubiquitin to one lysine residue in the protein, Multimonoubiquitination, the addition of single ubiquitin molecules to multiple lysine residues in the target protein and polyubiquitination, the addition of multiple ubiquitin residues to a single lysine residue in the protein in the form of a chain which can take a number of different conformations.

These modifications alter cellular process in different ways. Such as, monoubiquitination can impact on membrane trafficking; however, some forms of polyubquitination can result in a protein being targeted for degradation via the proteasome. The ubiquitin pathway has been implicated in a number of genetic disorders and diseases including cancer and neurological diseases which 
result from the build-up of protein aggregates such as; Alzheimer's disease, Parkinson's disease and Huntingdon's disease (horizon discovery.com). This sequence was isolated from the bulked low breeding value animals, and is associated with membrane trafficking which is essential in mammary glands.

This sequence when aligned against Bubalus bubalis genome using (wgs) database, it showed greater similarity, where this sequence resulted in similarity to chromosome 6 . This result showed the relation between some chromosome 6 expressed genes or sequences and milk production, this is also for chromosomes $\mathrm{X}, 4,23$ and 2. To relate the chromosome genes with low milk production validation experiments are required, in which the intended band was isolated from low bulked sample.

The third sequence had 534 nucleotides and showed similarity to the gene expressing acyl-phosphatase 2 (ACYP2). ACYP2 (Acylphosphatase 2) is a protein coding gene, and is a muscle type isozyme that can hydrolyze the phosphoenzyme intermediate of different membrane pumps, particularly the $\mathrm{Ca}^{2+} / \mathrm{Mg}^{2+}$-ATPase from sarcoplasmic reticulum of skeletal muscle (NCBI).

Two isoenzymes have been isolated, called muscle acylphosphatase and erythrocyte acylphosphatase on the basis of their tissue localization. This gene encodes the muscle-type isoform (MT). An increase of the MT isoform is associated with muscle differentiation. Acylphosphatase 2 is expressed in many different tissues including male and female tissues (breast) (NCBI). This sequence when aligned against Bubalus bubalis genome using (wgs) database, it showed greater similarity. This sequence resulted in similarity to chromosome 4 , where such result show the relation between some chromosome 4 expressed genes or sequences and milk production, this is also for chromosomes 3, 19, 13 and 10. This sequence was isolated from the bulked high breeding animals.

\section{CONCLUSION}

Microsatellite markers provide amplified parts of $\mathrm{k}$ casein gene, Leptin gene, and $\beta$ - lactoglobulin gene. A 262, 280 , and $247 \mathrm{bp}$ bands resulted from $\beta$ - lactoglobulin gene amplification which was then digested by Hae III enzyme. It is impossible to assess the influence of these genes on milk production traits, since all animals studied resulted in monomorphic profile.

SCoT primers were used after showing great similarity with buffalo sequence when aligned to it. They successfully amplified buffalo DNA samples, resulting in a monomorphic profile when used individually on the 20 samples.

SCoT primers were then used on two bulked samples representing the high and low milk yielders, this resulted in unique bands differentiating between high and low yielders, three of which were excited, purified and sequenced. The alignment of these sequences with Bubalus bubalis (taxid:89462) sequence (BLAST) in (NCBI) using $(\mathrm{nr} / \mathrm{nt})$ database showed similarity to three important genes expressing Class V myosins, Ubiquitin-conjugating enzyme E2 D4, and acyl-phosphatase 2 (ACYP2) proteins, which have a crucial role in many pathways and could be related to milk production traits. When aligning these sequences using (wgs) database, it showed much higher similarities but with no specific function with some buffalo chromosomes, which may have an important effect on milk production traits. Additional studies and investigations are recommended for the improvement of Egyptian buffalo milk genes.

\section{ACKNOWLEDGMENT}

Animal blood samples and animal records and data, were kindly provided by Animal Production Research Institute (APRI).

\section{REFERENCES}

Al-Soudy A., A. El-Sayed, H. El-Itriby , E. Hussein (2018). Assessment of the Genetic Diversity, Breeds Structure and Genetic Relationships in Four Egyptian Camel Breeds using Microsatellite and Start Codon Targeted (SCoT) Markers. Journal of Biodiversity \& Endangered Species. 6:S2. 10.4172/2332-2543.S2-00.

Borghese A. (2005). Buffalo production and research. Reu technical series 67. FAO 1-316.

Brinkmann B.,K. Michael, N. Franz; H. Julia, R.Burkhard (1998). Mutation Rate in Human Microsatellites: Influence of the Structure and Length of the Tandem Repeat. The American Journal of Human Genetics. 62 (6): 1408-1415.

Chen, X., Walker, A. K., Strahler, J. R., Simon, E. S., Tomanicek-Volk, S. L., Nelson, B. B., Hurley, M. C., Ernst, S. A., Williams, J. A., and Andrews, P. C. (2006). Organellar proteomics: analysis of pancreatic zymogen granule membranes. Mol. Cell Proteom. 5, 306-312.

Collard B. C. Y. \& David J. M. (2008). Start Codon Targeted (SCoT) Polymorphism: A Simple, Novel DNA Marker Technique for Generating GeneTargeted Markers in Plants. Plant Mol Biol Rep 27:86-93.

Damiani G, S Florio, E Budelli, P Bolla, ACaroli (2000). Single nucleotide polymorphisms (SNPs) within Bov-A2 SINE in the second intron of bovine and buffalo k-casein (CSN3) gene. Animal Genetics, 31, 277-279.

David Y., Ziv T., Admon A., Navon A.(2010). The E2 ubiquitin-conjugating enzymes direct polyubiquitination to preferred lysines, journal of Biological Chemestry, 285:8595-8604.

Deb K., Talukder N. Nahar ,Peregrino G. Duran and Giorgio A. Presicce. (2016), Safe and Sustainable Traditional Production: The Water Buffalo in Asia Gautam. Frontiers in Environmental Science, Volume 4, Article 38.

FAOSTAT 2017.

Gulcher J. (2012). Microsatellite markers for linkage and association studies. Cold Spring HarbProtoc. 4 (4): 425-432.

Hamad. M.N.E, M.M. El-Moghazy and M.E. Abdel-Aziz (2014). Phenotypic correlations among egyptian buffalo milk production and its major chemical constituents. Food and Dairy Sci., Mansoura Univ. 5 (10): $741-749$.

https://blast.ncbi.nlm.nih.gov/Blast.cgi

https://www.horizondiscovery.com

https://www.ncbi.nlm.nih.gov/gene?cmd=Retrieve\&dopt= full_report\&list_uids $=98$ 
Ilie D. E., A. Sălăjeanu, A. Magdin, R. Neamţ, and I. Vintila.(2010). Early Determination of Animals with Favorable Genes in Milk Production for Profitable Private Farms. Scientific Papers: Animal Science and Biotechnologies. 43 (1).

Jacobs D. T., Roberto W., Kyle D. G., Julie G. D., and Richard E. C.(2009). Myosin Vc Is a Molecular Motor That Functions in Secretory Granule Trafficking. Molecular Biology of the Cell. Vol. 20, 4471-4488.

Karimi.K, Mohammad T.B.S, Khalil M., Amin A., Hedayatallah R., and Jamal F.(2009). Polymorphism of the $\beta$-lactoglobulin gene and its association with milk production traits in Iranian Najdi cattle, Iranian journal of biotechnology, Vol. 7, No. 2.

Khedkar C.D., Kalyankar S.D. and Deosarkar S.S. (2016) Buffalo Milk. In: Caballero, B., Finglas, P., and Toldrá, F. (eds.). The Encyclopedia of Food and Health vol. 1, pp. 522-528. Oxford: Academic Press.

Marai. I.F.M and A.A.M. Habeeb. (2010). Buffalos' reproductive and productivetraits affected by heat stress.Tropical and Subtropical Agroecosystems, 193-217.

Marchelletta R. R., Jacobs D. T., Schechter J. E., Cheney R. E., and Hamm Alvarez, S. F. (2008). The class $\mathrm{V}$ myosin motor, Myosin $5 \mathrm{c}$, localizes to mature secretory vesicles and facilitates exocytosis in lacrimal acini. Am. J. Physiol. Cell Physiol. 295, C13-C28.

Meignanalakshmi S. and A.MahalingaNainar.(2009). PCR-RFLP analysis of beta-lacto globulin gene in Murrah buffaloes. Tamilnadu J. Veterinary \& Animal Sciences 5 (5) 194-197.

Olga C., Rodriguez and R. E. Cheney.(2002). Human myosin- $\mathrm{Vc}$ is a novel class $\mathrm{V}$ myosin expressed in epithelial cells, Journal of Cell Science 115, 9911004.

Orrù L., G.M. Terzano, F. Napolitano, M.C. Savarese, G. De Matteis, M.C. Scatà, G. Catillo, and B. Moioli.(2007). DNA Polymorphisms in River Buffalo Leptin Gene. Italian Journal of Animal Science. vol. 6, (Suppl. 2), 342-344.

Otaviano A.R., H. Tonhati'J. A. DesidérioSena' M. F. Cerón Muñoz (2005). Kappa-casein gene study with molecular markers in female buffaloes (Bubalus bubalis). Genet. Mol. Biol. vol.28 no.2
Pasha, T. N., and Khan, E. U. (2010). "Buffalo milk production in Pakistan," in Proceedings of the 9th World Buffalo Congress (Buenos Aires), 222-230.

Qureshi, M. S., Habib, G., Samad, H. A., Siddiqui, M. M., Ahmad, N., and Syed, S. (2002). Reproductionnutrition relationship in dairy buffaloes. Effect of intake of protein, energy and blood metabolites levels. Asian Aust. J. Anim. Sci. 15, 330-339.

Reinosa.O.U and A.A. Abad (2012). Molecular Tools in Buffalo's Characterization: Practical Applications. Journal of Buffalo Science, 1, 153-156.

Richard. G-F, A. Kerrest, and B. Dujon (2008). Comparative Genomics and Molecular Dynamics of DNA Repeats in Eukaryotes. MICRO BIOLOGY AND MOLECULAR BIOLOGY REVIEWS. 72 (4): 686-727

Rodriguez, O. C., and Cheney, R. E. (2002). Human myosin- $\mathrm{Vc}$ is a novel class $\mathrm{V}$ myosin expressed in epithelial cells. J. Cell Sci. 115, 991-1004.

Sarwar, M., Khan, M. A., Nisa, M., Bhatti, S. A., and Shahzad, M. A. (2009). Nutritional management for buffalo production. Asian Aust. J. Anim. Sci. 22, 1060-1068.

ShendeT.C , M.P. Sawane and V.D. Pawar. Tamilnadu J (2009). GENOTYPING OF PANDHARPURI BUFFALO FOR k-CASEIN USING PCR -RFLP. Veterinary \& Animal Sciences 5 (5) 174-178.

Stipp A.T. , PR Bignardi , RC Poly-Frederick, K. Sivieri, MR Costa (2013). Genetic polymorphisms of kappa-casein and beta-lactoglobulinandproduction of milk in cattle[ Kappa-casein and betalactoglobulin genetic polymorphisms and milk yield in bovines ]. Arq. Bras. Med. Vet. Zootec. v.65, n.1, p.275-280.

Tiwari, R., Sharma, M. C., and Singh, B. P. (2007). Buffalo calf health care in commercial dairy farms: a field study in Uttar Pradesh (India). Livest. Res. Rural Dev. 19, 38.

Vallinoto M., M. P. C. Schneider, A. Silva,L. Iannuzzi and B. Brenig.(2004).Molecular cloning and analysis of the swamp and river buffalo leptin gene. International Society for Animal Genetics Animal Genetics, 35, 462-504.

Wu.J-M, Y-R. Li, L-T. Yang, F-X. Fang, H-Z. Song, H-Q. Tang, M. Wang and M-L. Wing. (2013). cDNASCoT: A novel rapid method for analysis of gene differential expression in sugarcane and other plants. Australian journal of crop science 7(5):659664.

\footnotetext{
دراسة التباين الوراثي بين الجاموس المصرى Bubalus bubalis ذي الإنتاجية العالية و المنخفضة من الألبان

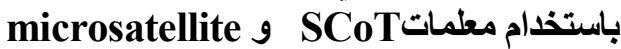

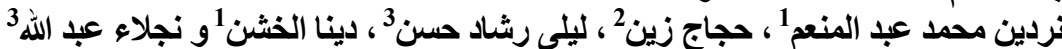

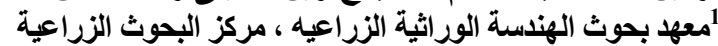

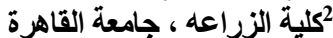
3معه بحوث الإنتاج الحيواني ، مركز البهاه البحوث الزراعية

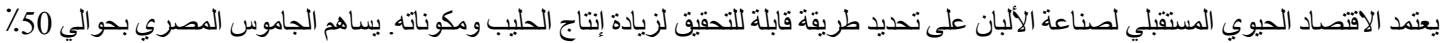

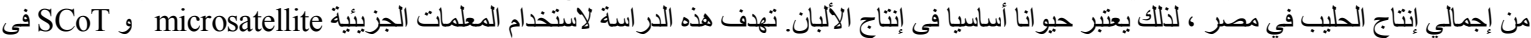

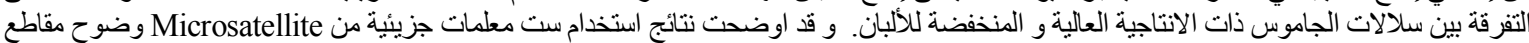

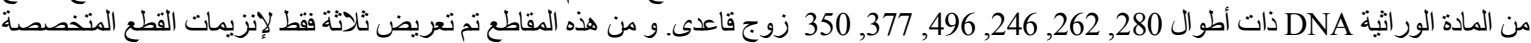

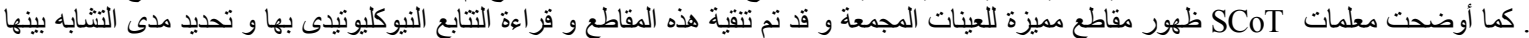

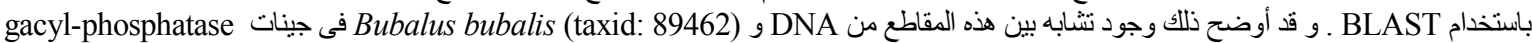
التي تلعب دورا هاما فى العديد من المسارات الحيوية داخل الحيوان و انتقال المركبات

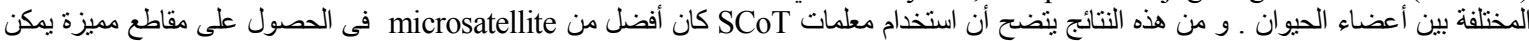
استخدامها للتفرقة بين الحيو انات ذات الإنتاجية العالية و المنخفضة للألبان فى الجاموس المصرى.
} 